DOI : $10.14746 /$ pp.2014.19.2.3

Krzysztof KOŹBIAt

Kraków

\title{
Ugrupowania polityczne mniejszości narodowych w Rumunii. Przykład Węgrów i Niemców
}

Streszczenie: Transformacja w Rumunii umożliwiła m.in. udział reprezentantów mniejszości narodowych w systemie politycznym państwa. Przykładem ilustrującym to zjawisko są Węgrzy, licząc wg spisu z 2011 r. ponad 1,237 mln osób, oraz Niemcy, liczący ok. 37 tys. osób.

Obie grupy biorą regularny, aktywny udział $\mathrm{w}$ wyborach na szczeblu ogólnopaństwowym jak i lokalnym. Wegrzy są reprezentowani przez UDMR, ugrupowanie osiągające poparcie wyższe niż 5\% głosów, co umożliwia regularne posiadanie w Izbie Deputowanych ponad 20, a w Senacie około 10 miejsc. Niemcy są z kolei reprezentowani przez FDGR. Dużo niższe poparcie przekłada się na zaledwie 1 miejsce w parlamencie. Mniejszości te odgrywają istotną rolę w wyborach lokalnych, także Niemcy, przykładem wyborczych sukcesów jest miasto Sibiu.

W przyszłości nie należy oczekiwać zasadniczej zmiany w znaczeniu odgrywanym przez obie grupy. W odróżnieniu od Węgrów, poparcie dla Niemców jest wyższe niż liczebność grupy. Jest to pochodną faktu, iż kwestia mniejszości niemieckiej w Rumunii nigdy nie wywoływała takich napięć jak Węgrzy, zarówno w stosunkach wewnętrznych, jak i międzypaństwowych. $Z$ tego powodu oddanie glosu na FDGR nie musi się łączyć z przynależnością do mniejszości niemieckiej, co pozwala na pozyskanie wyborców.

Slowa kluczowe: Rumunia, Siedmiogród, mniejszość narodowa, Węgrzy, Niemcy

$\mathbf{T}$ ransformacja ustrojowa, która dokonała się w Europie Środkowowschodniej po 1989 r. wpłynęła w sposób pozytywny na sytuację i realizowane w praktyce prawa licznych w tej części kontynentu mniejszości narodowych. Uzyskały one przede wszystkim możliwość swobodnego zrzeszania i stowarzyszania się, uznanie swych praw oraz perspektywę posiadania swoich reprezentantów w izbach parlamentarnych. Nie mniej ważna stała się reprezentacja w gremiach samorządowych, na szczeblu lokalnym czy regionalnym.

Przykładem państwa, w którym obserwowano tego typu przemiany ustrojowe jest Rumunia. Spektakularne pozbawienie władzy Nicolae Ceausescu doprowadziło do daleko idących przemian systemu politycznego i partyjnego państwa. Pojawiły się ugrupowania polityczne chcące pozyskać głosy ludności nierumuńskiej. Wśród nich na czoło wysunęły się te, które reprezentują ludność wegierską i niemiecką. Nie jest to przypadek, bowiem to właśnie Wegrzy i Niemcy należą do najliczniejszych mniejszości narodowych w Rumunii.

Autor stawia hipotezę, iż po 1989 r. ugrupowania reprezentujące mniejszość węgierską i niemiecką stały się trwałym czynnikiem systemu partyjnego Rumunii. Na szczeblu ogólnopaństwowym istotniejsze znaczenie mieli Węgrzy - obecni nawet w koalicjach rządowych, na szczeblu lokalnym ważna rola przypadła mniejszości niemieckiej, szczególnie w Siedmiogrodzie. Ugrupowanie mniejszości węgierskiej jest jednak 
„zamknięte etnicznie” i liczy w praktyce tylko na poparcie Węgrów. Przeciwnie Niemcy popierani także przez inne grupy etniczne, a tym samym rozszerzający swój potencjalny elektorat.

Przygotowując artykuł, autor wykorzystał przede wszystkim metodę badawczą w postaci analizy systemowej, skupiając się na działaniu partii politycznych dwóch wybranych mniejszości będących składnikami systemu partyjnego w omawianym państwie. Poza tym zastosowano metodę analizy instytucjonalno-prawnej, rozpoznając akty normatywne dotyczące sytuacji analizowanych grup, oraz metodę historyczna, pomocną głównie przy przedstawieniu genezy współczesnych zjawisk politycznych dotyczących Węgrów i Niemców w granicach państwa rumuńskiego.

\section{Tło historyczne, rozmieszczenie oraz liczebność Węgrów i Niemców w Rumunii}

Trudność stanowi dokładne określenie kiedy omawiane grupy ludności pojawiły się na obszarach wchodzących w skład współczesnej Rumunii. Krainą, w której się osiedliły, był Siedmiogród znajdujący się wówczas w granicach Węgier. Jednak bezsprzecznie pierwotną ludnością tego obszaru byli Rumuni. W ramach tzw. kolonizacji na prawie niemieckim w XII stuleciu przybyli do tego regionu Sasi Siedmiogrodzcy. Wg niektórych opracowań ich osadnictwo rozpoczęło się w 1143 roku (Deutsches, s. 54). Grupa niemiecka w Rumunii nigdy nie była jednolita. Rozróżniano bowiem, oprócz Sasów, tzw. Szwabów z Banatu, Niemców z okolic Satu Mare, Niemców z Dobrudży, Besarabii i Bukowiny. Te ostatnie 3 grupy zostały wysiedlone do Niemiec w czasie II wojny światowej w ramach nazistowskiej akcji Heim ins Reich.

Siedmiogród należał wówczas do Wegier, które osadzały tam Seklerów mających bronić tych ziem przed najazdami Połowców, Kumanów i Pieczyngów (Willaume, 2007, s. 90). Węgrzy opanowali Siedmiogród w kilku fazach między X a XIII stuleciem (Nägler, 1999, s. 27-28).

Zarówno Sasi, jak i Seklerzy pozostali w tej części Europy do dziś. Niemcy pozostający w najstarszych skupiskach nie asymilowali się z pozostałymi grupami, pielęgnując swe zwyczaje i język. Z czasem zostali poddani madziaryzacji, szczególnie nasilonej w drugiej połowie XIX w., i częściowo jej ulegli (Kopyś, 2001, s. 44).

Rumunia w obecnych granicach funkcjonuje od zakończenia II wojny światowej. Państwo rumuńskie powstało w II połowie XIX stulecia, jego późniejsze granice ulegały rozszerzeniu. W konsekwencji po zakończeniu I wojny światowej powstała tzw. Wielka Rumunia o obszarze ponad 295 tys. $\mathrm{km}^{2}$ (obecnie powierzchnia państwa wynosi ponad 238 tys. $\mathrm{km}^{2}$ ). Początkowo nie obejmowała swymi granicami Siedmiogrodu ani Banatu - obszarów, na których grupy ludności wegierskiej i niemieckiej byly i są stosunkowo liczne. Oba regiony znajdowały się do $1918 \mathrm{r}$. w granicach Węgier, te z kolei stanowily część monarchii austro-węgierskiej.

Po 1918 roku odsetek mniejszości narodowych w państwie rumuńskim raptownie wzrósł z 8 do prawie 30 procent. Rumunia stała się państwem wielonarodowym, choć wbrew faktom jej konstytucja z 1923 r. już w art. 1 głosiła, że jest to państwo narodowo jednolite. Mniejszości zapewniły sobie reprezentację polityczną w nowym parlamencie 
rumuńskim; byli tam reprezentowani zarówno Węgrzy, jak i Niemcy (Willaume, 2004, s. 97-101).

Już wówczas mniejszości zorganizowały się w ugrupowania mające reprezentować ich interesy. Nie były one jednolite poglądowo, dochodziło w nich do rozłamów. Węgrów reprezentowała m.in. Narodowa Partia Węgierska, Partia Węgiersko-Seklerska, Węgierski Związek Ludu Pracującego, wreszcie Partia Drobnych Właścicieli Węgierskich. Mniejszość niemiecka powołała do życia Unię Niemców z Rumunii, Związek Niemców w Rumunii, Partię Niemiecką, wreszcie Ruch Samopomocy Niemców z Rumunii i Partię Narodu Niemieckiego. W działalności ugrupowań niemieckich lat 30 . dały o sobie znać czynniki narodowosocjalistyczne (Willaume, 2004, s. 110-111).

Obie grupy starały się odgrywać doniosłą rolę w polityce wewnętrznej Rumunii. Wynikało to m.in. z ich liczebności. Według danych ze spisu ludności z 1930 r. na terytorium omawianego państwa zamieszkiwało 1,42 mln Węgrów i 745 tys. Niemców. Stanowili, odpowiednio, 7,9 oraz 4,1\% ludności, będąc najliczniejszymi mniejszościami (Willaume, 2004, s. 118).

W czasie wojny Siedmiogród został włączony do Wegier pozostających w koalicji z III Rzeszą. Wtedy też prześladowań doświadczyła miejscowa ludność rumuńska. Z kolei wśród części Niemców rumuńskich tendencje nazistowskie wyraziły się tworzeniem organizacji znanych z III Rzeszy, np. Deutsche Jugend czy Bund Deutscher Mädel. Niemcy zdolni do noszenia broni byli propagandowo zachęcani do wstępowania w szeregi Waffen-SS, co na terenie Rumunii przyniosło skutek w postaci 48 tys. zwerbowanych (Böhm, 2003, s. 318).

Po zakończeniu II wojny światowej obie grupy, mimo że stosunkowo liczne, nie odgrywały istotnej roli. Nie było mowy o ich reprezentacji politycznej w rumuńskim parlamencie. Polityka Bukaresztu wobec grup mniejszościowych nie odbiegała zasadniczo od ówczesnego „wzorca” postępowania w innych krajach socjalistycznych: prawa mniejszości były zapewniane w teorii, w praktyce ich nie realizowano, mimo stwarzania pozorów w tym zakresie.

Od 1952 r. formalnie istnial tzw. Węgierski Region Autonomiczny, lecz od innych regionów państwa różnił się jedynie nazwą, gdyż prawnie Wegrzy nigdy nie posiadali w nim żadnej formy autonomii. Istniejące ugrupowania węgierskie rozwiązano zarzucając im „odchylenia nacjonalistyczne”. Jedyną formą pielęgnowania odrębności było dopuszczenie do nauki w językach mniejszości w szkołach. W $1945 \mathrm{r}$. władze rumuńskie pozwolity na ponowne otwarcie bogatego w tradycje uniwersytetu wegierskiego Bolyai w Cluj, lecz w $1959 \mathrm{r}$. został on połączony z rumuńskim uniwersytetem Babes w tym samym mieście. Szykanę stanowiło usuwanie dwujęzycznych nazw i napisów (Mihok, 1999, s. 73-77).

Stosunek do niemieckiej grupy narodowościowej w Rumunii był pochodną okresu wojennego. Niemcy częściowo podlegali deportacjom przymusowym do pracy w ZSRR (jesienią 1944 r. deportowano ok. 70 tys. osób), tracili swoje dobra w toku nacjonalizacji, de facto przez kilka lat znajdowali się poza prawem. Ograniczeniom poddane zostało szkolnictwo w języku niemieckim. Ich dalszy los związany był z próbą ,integracji”" z resztą społeczeństwa rumuńskiego (Hartl, 1987, s. 87-93).

Okres powojenny charakteryzował się także spadkiem liczebności grupy niemieckiej. Stanowiło to następstwo porozumień zawartych między Bukaresztem a Bonn jeszcze pod 
koniec lat 60. Ceausescu zgodził się wówczas na emigrację Niemców z Rumunii (w latach 1967-1989 wyjechało ich ok. 200 tys.) w zamian za rekompensatę finansową sięgającą nawet do 10 tys. marek niemieckich za osobę (Willaume, 2004, s. 221-222). Według niektórych obliczeń w latach 1950-1993 z Rumunii do Niemiec wyjechało ponad 407 tys. Niemców (Sterbling, 1997, s. 76). Z kolei liczebność mniejszości węgierskiej pozostała $\mathrm{w}$ miarę stabilna.

Współczesne dane dotyczące mniejszości narodowych w Rumunii oparte są o spisy powszechne. W okresie po transformacji przeprowadzono je w latach 1992, 2002 i $2011^{1}$. Zestawienie z 2011 r. wykazało, iż Rumuni stanowią 88,6\% mieszkańców państwa, Węgrzy i Seklerzy 6,5\% (prawie 1,24 mln) a Niemcy 0,2\% (prawie 37 tys.) (Romania, s. 11). Tym samym dwie ostatnie grupy należa, oprócz Ukraińców i Romów, do najliczniejszych grup mniejszościowych. W spisach z 1992 i 2002 r. odnotowano zauważalnie więcej Węrów (odpowiednio: ponad 1,62 oraz 1,44 mln) oraz znacznie więcej Niemców (odpowiednio: ponad 119 i prawie 60 tys.) (Janusz, 2006, s. 40). Warto zauważyć, iż czynnik religijny nie odgrywa większej roli w identyfikacji omawianych mniejszości (Solak, 2004, s. 71).

Węgrzy zamieszkują przede wszystkim w Siedmiogrodzie, szczególnie w okręgach (województwach) Harghita i Covasna, gdzie stanowia, odpowiednio, ok. 85 i prawie $74 \%$. Z kolei Niemcy skupiają się obecnie głównie w Siedmiogrodzie (Sibiu, Medias i okolice) oraz w Banacie.

Wyjazdy członków mniejszości niemieckiej z Rumunii do RFN miały miejsce jeszcze w latach 90. minionego wieku. Przybysze z Rumunii stanowili jedną z największych grup napływających do Niemiec, jako tzw. późni przesiedleńcy. Był to podstawowy powód ograniczenia rozmiaru tej mniejszości w granicach państwa rumuńskiego. Zestawienie liczebności omawianych mniejszości w latach 1930-2011 przedstawiono w tabeli 1.

\section{Liczebność Węgrów i Niemców w Rumunii w latach 1930-2011 (w tys.)}

\begin{tabular}{|c|c|c|}
\hline Rok & Wegrrzy & Niemcy \\
\hline 1930 & 1425,5 & 745,4 \\
\hline 1956 & 1587,6 & 384,7 \\
\hline 1966 & 1619,6 & 382,6 \\
\hline 1977 & 1706,8 & 358,7 \\
\hline 1992 & 1620,2 & 119,1 \\
\hline 2002 & 1431,8 & 59,8 \\
\hline 2011 & 1237,7 & 36,9 \\
\hline
\end{tabular}

Źródlo: Mihok, 1999, s. 73; Kroner, 1997, s. 59; Janusz, 2006, s. 40 ; Romania, s. 11 .

\footnotetext{
${ }^{1}$ Wyniki spisu przeprowadzonego w 2011 r. są znane jedynie cząstkowo, wg stanu na dzień 30 czerwca 2013 r.
} 


\section{Mniejszości narodowe we wspólczesnej Rumunii i ich prawa. Aktywność wyborcza}

W okresie transformacji ustrojowej Rumunia stała się bez wątpienia państwem demokratycznym. Podkreślały to szczegółowe zapisy nowej konstytucji, uchwalonej 21 listopada 1991 r.. Część z nich w sposób de facto bezpośredni dotyczyła mniejszości narodowych. W ustawie zasadniczej bardzo wyraźnie zaznaczano jednak, że Rumunia jest państwem narodowym, jednolitym i niepodległym, w praktyce wykluczając perspektywę odłączenia od państwa jakiejkolwiek jego części. Rozdział II konstytucji zawiera zapisy o prawach podstawowych, wolnościach i obowiązkach człowieka i obywatela. Podkreślono gwarancje równości wobec prawa, nienaruszalność wyrażania myśli, poglądów i wiary, możliwość tworzenia partii politycznych i stowarzyszeń (Brodziński, 2006, s. 13-18).

Zarejestrowanym organizacjom, które zrzeszają mniejszości narodowe artykuł 59 najwyższej ustawy w państwie gwarantuje posiadanie reprezentacji parlamentarnej, pod warunkiem uzyskania odpowiedniej liczby głosów wyborców. Aby tak się stało organizacja mniejszości w wyborach do Izby Deputowanych musiała, od 1992 r., otrzymać poparcie na poziomie nie mniejszym niż 5\% średniej liczby głosów potrzebnych do uzyskania mandatu parlamentarnego. W roku 2008 próg ten podniesiono do $10 \%$ (Brodziński, 2006, s. 20; Batko-Jakubiak, 2010, s. 294).

Obecnie w Izbie Deputowanych reprezentowanych jest 18 ugrupowań mniejszościowych, m.in. Polacy ${ }^{2}$. Grupy te tworzą wspólną 18-osobową Grupę Parlamentarną Mniejszości Narodowych - 1 miejsce przypada na każdą z wymienionych mniejszości. (www.ipu.org..., 28.05.2013). Dziewiętnastą grupą są Węgrzy, lecz dostali się oni do parlamentu nie korzystając z uprzywilejowujących mniejszości przepisów. Obecnie ich reprezentacja jest 18-osobowa.

Rozwiązania dotyczące położenia grup mniejszościowych, przyjęte na początku lat 90. minionego wieku, zostały oprotestowane, szczególnie przez mniejszość węgierską. Już w czasie prac parlamentarnych krytykowano określenie Rumunii mianem państwa jednolitego i ustanowienie jedynym językiem urzędowym rumuńskiego. Wegrzy opowiadali się za przyjęciem określenia „państwo wielonarodowe”, domagając się jednocześnie, aby węgierski był - obok rumuńskiego - językiem stosowanym w administracji i w postępowaniu przed sądem. Z kolei przedstawiciele mniejszości niemieckiej zwracali uwagę na brak grupowego uznania praw mniejszości (Gabanyi, 1998, s. 229-231).

Od kwietnia 1993 r. funkcjonuje Rada ds. Mniejszości Narodowych. Jest to organ o charakterze konsultacyjnym, skupia się na bieżących kwestiach prawnych, administracyjnych i finansowych związanych z mniejszościami. W Radzie reprezentowane są organizacje 19 mniejszości, tych samych, które zasiadają w parlamencie (Maksimiec, 2012, s. 89-90). W gestii Rady leży nawiązywanie i podtrzymywanie kontaktów z przedstawicielami mniejszości, składanie projektów ustaw i uchwał rządowych, które dotyczą

\footnotetext{
${ }^{2}$ Oprócz Związku Polaków w Rumunii są także ugrupowania reprezentujące: Albańczyków, Bułgarów, Chorwatów, Czechów (Słowacy pozostają z nimi we wspólnym związku), Greków, Macedończyków, Niemców, Ormian, Romów, Rosjan, Rusinów, Serbów, Tatarów, Turków, Ukraińców, Wlochów i Żydów.
} 
mniejszości (oraz opiniowanie propozycji ministerialnych w tym zakresie), kontakt z władzami administracyjnymi niższego szczebla w celu rozpoznawania potencjalnych problemów, względnie proponowanie gabinetowi rozwiązań w tym zakresie (Maksimiec, 2012, s. 90). Praktyczna działalność Rady, przynajmniej w początkowym okresie, była jednak oceniana przez ugrupowania mniejszościowe krytycznie. Uznawały one, że Rada jest narzędziem nieefektywnym i nie przyczynia się do normalizacji ich sytuacji (Mihok, 1999, s. 95-101).

W państwie rumuńskim nie obowiązuje specjalna, osobna ustawa, która regulowałaby prawa mniejszości narodowych, mimo że na początku lat 90 . pojawiły się próby wypracowania, a następnie przyjęcia takiego dokumentu. Jednakże zarówno propozycje przedstawione przez mniejszość niemiecką, wegierską, jak i Radę ds. Mniejszości Narodowych, nie przyniosły żadnych konkretnych rezultatów (Tontsch, 1995, s. 164-168). Oprócz wspomnianych przepisów konstytucyjnych prawa mniejszości gwarantowane są przez akty międzynarodowe ratyfikowane przez rząd w Bukareszcie ${ }^{3}$.

Odpowiednie zapisy umożliwiają funkcjonowanie na obszarze Rumunii szkolnictwa w językach ojczystych poszczególnych mniejszości. Ramy prawne ich działania określiła ustawa z 1995 r., znowelizowana rok później. W roku szkolnym 1995/96 w Rumunii funkcjonowało ponad 2400 oddziałów szkolnych i przedszkolnych z wegierskim językiem wykładowym, w przypadku języka niemieckiego było ponad 270 oddziałów (Tontsch, 2001, 12.05.2013). Jeśli chodzi o tę drugą grupę, liczba ta zmniejszała się. W roku szkolnym 2011/2012 w języku węgierskim naukę w trybie przedszkolnym pobierało ponad 43 tys. dzieci, w szkołach typu podstawowego i gimnazjalnego ponad 87 tys., a w szkołach średnich prawie 37 tys. uczniów. Analogiczne dane dla języka niemieckiego wynosiły, odpowiednio, ponad 6, ponad 11 i ponad 3 tys. uczniów (Anuarul, 2013, s. 254).

Jak wspomniano, obie grupy zamieszkują na stosunkowo zwartych obszarach. W związku z tym istotnego znaczenia nabrały rozwiązania prawne dotyczące możliwości posługiwania się językiem ojczystym w swoim miejscu zamieszkania, w kontaktach z władzami lokalnymi. Kwestie te zostały uregulowane przez ustawę o lokalnej administracji publicznej z 2001 r. Członkowie mniejszości mają możliwość używania swego języka ojczystego w kontaktach z władzami w miastach lub gminach, w których stanowią przynajmniej $20 \%$ ludności. Poziom ten określany jest na podstawie danych z aktualnych spisów powszechnych. W takich przypadkach rady tychże jednostek administracyjnych są zobowiązane do informacji na temat obrad w języku mniejszości, w nim też publikowane sq̨ akty normatywne. Jeśli przedstawiciele mniejszości stanowią co najmniej 1/3 składu rady, wówczas podczas obrad istnieje możliwość używania języka mniejszości. Wszystkie dokumenty muszą być jednak sporządzane w języku rumuńskim (Gesetz Nr. 215).

Podobna regulacja, wziąwszy pod uwagę wymóg minimum 20\% ludności należącej do mniejszości na obszarze gmin, obowiązuje jeśli chodzi o stosowanie nazw miejscowo-

\footnotetext{
${ }^{3}$ Rumunia jest stroną Konwencji Ramowej Rady Europy o ochronie mniejszość narodowych oraz Europejskiej Karty języków regionalnych i mniejszościowych zatwierdzonej także w ramach prac Rady Europy.
} 
ści w języku ojczystym mniejszości. Przepisy te są realizowane w praktyce, o czym najlepiej można się przekonać, poruszając się po Rumunii, zwłaszcza po Siedmiogrodzie. Z możliwości tej korzystają zarówno Węgrzy, jak i Niemcy.

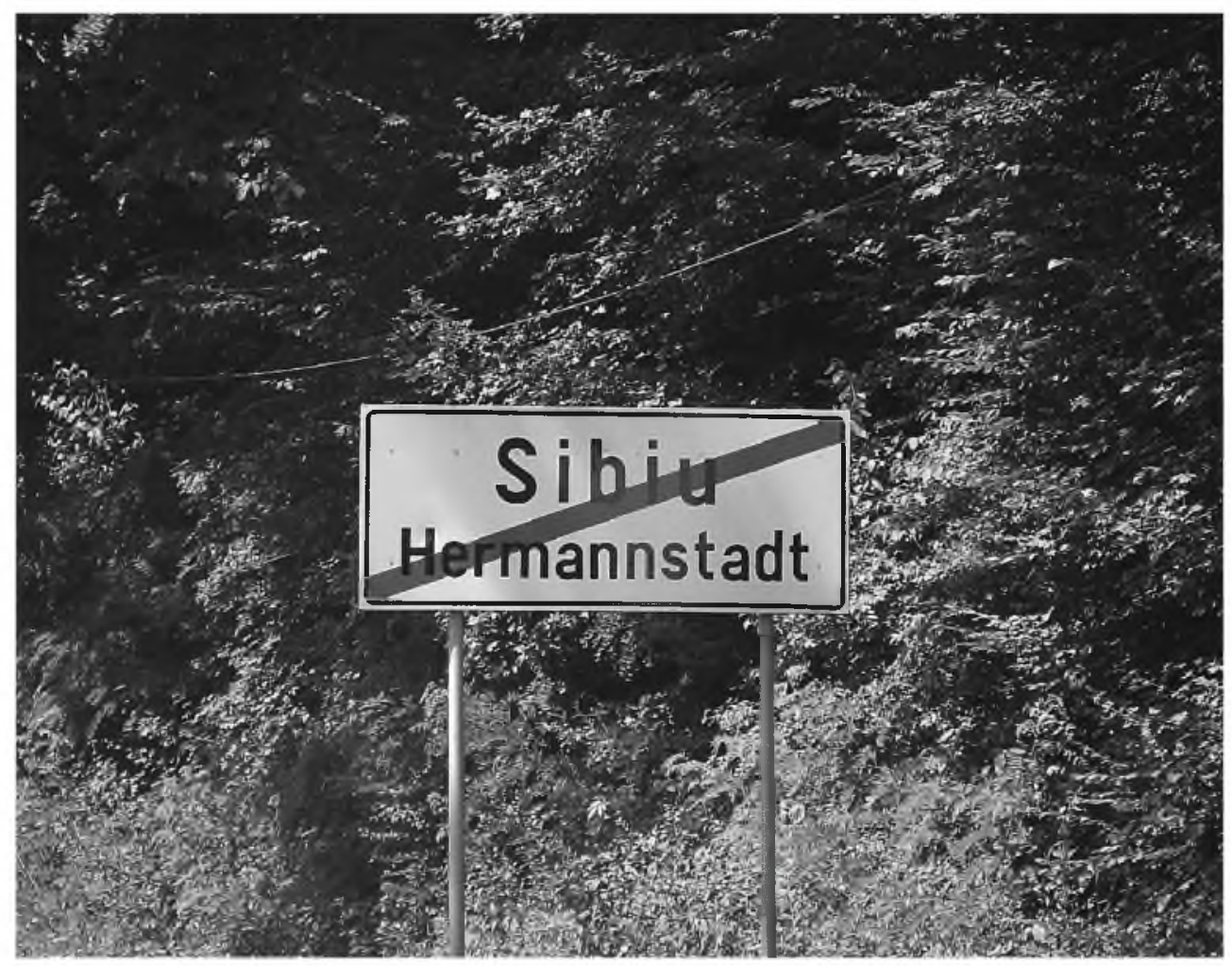

Zdjęcie 1. Tablica dwujęzyczna w Sibiu

Fot. Krzysztof Koźbiał.

Od początku transformacji ustrojowej mniejszości miały możliwość brania aktywnego udziału w wyborach. Pierwsze demokratyczne wybory w Rumunii, po upadku Ceausescu, odbyły się w maju 1990 roku. Uczestniczyły w nich powstałe do tego momentu organizacje mniejszości narodowych, które miały zagwarantowane co najmniej jedno miejsce, dla każdej, w Izbie Deputowanych, nawet w przypadku gdyby nie uzyskały liczby głosów potrzebnych aby znaleźć się w parlamencie. Niezbędną liczbę głosów (wynoszącą wówczas 3\% w skali kraju) uzyskali tylko przedstawiciele mniejszości wegierskiej - nie było to zaskoczenie, biorąc pod uwagę liczebność grupy.

Wybory z 1992 r. przeprowadzono wg nowej ordynacji. Mniejszości miały odtąd prawo do reprezentacji w parlamencie, jeżeli uzyskały przynajmniej 5\% średniej liczby głosów potrzebnych do uzyskania mandatu. W tym przypadku liczba ta wynosiła 1327 głosów (Tontsch, 1995, s. 161). Nie był to zatem próg szczególnie wygórowany, w skali całego kraju, stąd w parlamencie znaleźli się odtąd przedstawiciele kilkunastu mniejszości narodowych, w 1992 r. było to 13 grup. 


\section{Mniejszość węgierska i jej ugrupowania}

Do utworzenia ugrupowania, które poczęło reprezentować interesy mniejszości węgierskiej doszło tuż po upadku Ceausescu. 25 grudnia 1989 r., podczas spotkania wegierskich intelektualistów i działaczy lokalnych powołano do życia Demokratyczny Związek Węgrów w Rumunii (rum. Uniunea Democrată Maghiară din România - UDMR, węg. - Romániai Magyar Demokrata Szövetség - RMDSZ) niebędący partią, lecz grupą jednoczącą różne środowiska węgierskie. Na czele UDMR stanął pierwotnie Géza Domokos (Burakowski, Stan, 2012, s. 47; Gabanyi, 1998, s. 297). Postacią charyzmatyczną ruchu mniejszości wegierskiej był od początku transformacji pastor z Timisoary, aktywny w czasie antykomunistycznych protestów w tym mieście w grudniu 1989 r., László Tökés. W 2003 r. na kongresie UDMR zapobieżono rozłamowi w ugrupowaniu pozbawiając Tökésa funkcji honorowego przewodniczącego (Burakowski, Stan, 2012, s. 188).

W początkach swej działalności Związek prowadził tzw. kurs defensywny nie reagując na liczne ataki słowne i medialne ze strony rumuńskiej, m.in. ze strony partii o charakterze nacjonalistycznym. Zmiana podejścia Węgrów uwidoczniła się po przyjęciu w październiku 1992 r. tzw. deklaracji z Cluj (węg. Kolozsvári Nyilatkozat). Był to początek ofensywy politycznej nakierowanej na wskazanie, iż sprawy mniejszości nie zostały dotąd rozwiązane. UDMR częściowo wskazywał organizacjom i gremiom międzynarodowym, iż w jego ocenie kwestie mniejszości narodowych w Rumunii powinny być poddane bacznej obserwacji. Działania te zbiegły się ze staraniami Rumunii o przyjęcie do Rady Europy (co nastapiło ostatecznie w 1993 r.) i z tej okazji Związek wydał specjalne memorandum adresowane do Sekretarza Generalnego Rady wskazując, iż Rumunia nie przestrzega praw mniejszości (Mihok, 1999, s. 104-110). Niewątpliwie powodowało to wzrost wewnętrznego, ale i zewnętrznego, napięcia politycznego.

Organizacja od 1990 roku brała udział w wyborach zarówno na szczeblu lokalnym, jak i ogólnopaństwowym. Odnosiła w nich sukcesy, na miarę swoich możliwości. Podczas pierwszych demokratycznych wyborów w $1990 \mathrm{r}$. UDMR była jedyną organizacją mniejszości, która pokonała barierę niezbędną do uzyskania miejsc w parlamencie w sposób bezpośredni. Związek wprowadził do Izby Deputowanych 29 posłów, do Senatu 12 senatorów. Wynik był niewątpliwym sukcesem, gdyż większą liczbę przedstawicieli w parlamencie miały tylko ugrupowania współpracujące w ramach Frontu Ocalenia Narodowego. Poparcie wyborcze dla UDMR w wyborach parlamentarnych przeprowadzonych po 1989 r. wyszczególniono w tabeli 2.

Tabela 2

Poparcie dla UDMR w wyborach parlamentarnych w Rumunii po 1989 r.

\begin{tabular}{|c|c|c|c|c|c|}
\hline Rok & $\begin{array}{c}\text { Izba } \\
\text { Deputowanych }\end{array}$ & Senat & Rok & $\begin{array}{c}\text { Izba } \\
\text { Deputowanych }\end{array}$ & Senat \\
\hline 1990 & 7,23 & 7,20 & 2004 & 6,17 & 6,23 \\
\hline 1992 & 7,46 & 7,58 & 2008 & 6,59 & 6,39 \\
\hline 1996 & 6,64 & 6,82 & 2012 & 5,13 & 5,23 \\
\hline 2000 & 6,80 & 6,90 & & & \\
\hline
\end{tabular}

Źródlo: Burakowski, Stan, 2012, passim; Gabanyi, 1998, s. 299; Alegeri pentra..., 2012. 
Poparcie wyborcze należy uznać za niezwykle stabilne, przekraczające najczęściej 6\% głosów. Jedynie w elekcji z 1990 i 1992 roku było ono nieznacznie wyższe. Spadek głosujących na UDMR w grudniu 2012 r. należy wiązać przede wszystkim z tym, iż wystartowało także drugie ugrupowanie Węgrów w Rumunii, które uzyskało w wyborach do Izby Deputowanych $0,64 \%$, a w wyborach do Senatu $0,79 \%$ poparcia. Nie przełożyło się to na uzyskanie miejsc w izbach parlamentarnych. Ostatecznie UDMR wprowadziła 18 posłów do Izby Deputowanych i 8 przedstawicieli do Senatu. W obu izbach Wegrzy tworzą własne grupy parlamentarne. W Izbie Deputowanych na czele grupy stoi András Máté, w Senacie Béla Markó (www.cdep.ro, www.senat.ro, 29.05.2013). Ugrupowanie pozostaje w opozycji do obecnego gabinetu premiera Victora Ponty.

Były jednak okresy, w których Związek uczestniczył w formowaniu koalicji rządowej. $Z$ powodu zauważalnego udziału w podziale miejsc $w$ parlamencie, ugrupowanie mniejszości węgierskiej znalazło się w latach 1996-2000, 2004-2008 oraz 2009-2012 w koalicji rządowej (Szász, 2003, s. 103; Aron, 2009, s. 47-48). W tym ostatnim gabinecie wicepremierem był wspomniany Belá Markó (Burakowski, Stan, 2012, s. 252-254). Ponad 20 miejsc w Izbie Deputowanych było ważnym czynnikiem wpływającym na stabilizacje większości poszczególnych gabinetów. W latach 2000-2004 UDMR wspierał w poszczególnych głosowaniach rząd mniejszościowy choć nie należał do koalicji (Szász, 2003, s. 105-111).

Partia mniejszości węgierskiej jest zauważalnym uczestnikiem wyborów na szczeblu lokalnym. Potwierdzają to wyniki wyborów z czerwca 2012 roku. Dwóch przedstawicieli mniejszości stoi na czele wybieralnych samorządów na szczeblu okręgów (województw), 203 zajmuje stanowisko będące odpowiednikiem polskiego prezydenta miasta, burmistrza lub wójta (w zależności od jednostki administracyjnej), 2261 osób reprezentuje grupę w radach na poziomie samorządów lokalnych, 88 na szczeblu okręgów ${ }^{4}$ (Alegeri locale..., 2012).

Ugrupowanie brało także udział, wystawiając swoich kandydatów, w wyborach na urząd prezydenta Rumunii. W roku 1996 i 2000 kandydował na to stanowisko György Frunda uzyskując, odpowiednio, ponad 6 oraz $6,2 \%$ głosów. Startujący w wyborach z 2009 r. Hunor Kelemen uzyskał widocznie niższe poparcie - 3,8\% głosów (Burakowski, Stan, 2012, s. 115, 171, 250).

Po przystąpieniu Rumunii do Unii Europejskiej państwo to otrzymało miejsca do obsadzenia w Parlamencie Europejskim. Wybory do niego stały się zatem kolejną areną współzawodnictwa partyjnego. Zarówno w kadencji 2007-2009, jak i od 2009 r. ugrupowanie reprezentujące mniejszość węgierską obsadziło 3 z 33 miejsc przewidzianych dla Rumunii. Obecnie w Parlamencie Europejskim zasiadają Csaba Sógor, László Tökés i Iuliu Winkler. Wszyscy są członkami Grupy Europejskiej Partii Ludowej (Chrześcijańscy Demokraci) (www.europarl..., 28.05.2013). Także w poprzedniej kadencji te 3 osoby reprezentowały omawianą mniejszość, choć Tökés był wówczas parlamentarzystą niezależnym.

\footnotetext{
${ }^{4}$ Oprócz tego innemu ugrupowaniu tejże mniejszości udało się osiagnać 7 stanowisk burmistrzów lub wójtów, wprowadzić 266 przedstawicieli do rad samorządów lokalnych i 7 do rad na poziomie okręgów.
} 
Mniejszość węgierska w Rumunii, głównie poprzez swoją zauważalną liczebność i zgrupowanie na zwartym obszarze, wywoływała niejednokrotnie emocje, także w okresie po upadku dyktatury Ceausescu. Jej obecność była także wykorzystywana w rozgrywkach na scenie politycznej.

Do największych rozruchów o charakterze narodowościowym w okresie powojennym doszło w marcu 1990 r. w Târgu Mureș. W odpowiedzi na założenie koła UDMR w tym mieście rumuńscy nacjonaliści zainicjowali działalność Związku „Ogniwo Rumuńskie" (rum. Vatra Românească). Do Siedmiogrodu przyjeżdżali wtedy także masowo Węgrzy chcący świętować rocznicę powstania z 15 marca 1848 r., co dodatkowo potęgowało emocje. W kolejnych dniach doszło do krwawych rozruchów, ukazywanych dodatkowo w krzywym zwierciadle przez media zagraniczne. Uspokojenie nastrojów stało się możliwe dopiero po interwencji wojska. W konsekwencji zajść śmierć poniosło 6 osób, prawie 300 zostało rannych (Burakowski, Stan, 2012, s. 53-54).

W 1995 r. skorzystano z ,węgierskiego straszaka” kiedy Rumuńska Partia Demokracji Społecznej (PDSR) rozszerzyła koalicję rządzącą o ugrupowania o charakterze nacjonalistycznym. Wśród nich prym wiodła Rumuńska Partia Zjednoczenia Narodowego (PUNR). Radykałowie tego ugrupowania, zdecydowanie antywęgierskiego, objęli 2 resorty. O tym, iż były to działania o charakterze doraźnym, wykorzystujące nastroje chwili, świadczy fakt, iż po kilku latach UDMR była wymarzonym koalicjantem PDSR (Solak, 2004, s. 81-82).

Pod koniec 2001 r. parlamentarna komisja kontroli służb specjalnych ostrzegała władze państwowe przed rzekomym zagrożeniem, jakie miały nieść nastroje Wegrów w okręgach, w których grupa ta była najliczniejsza. Analitycy ówczesnej Rumuńskiej Slużby Informacyjnej stwierdzali nawet, iż realna jest groźba utraty kontroli rządu centralnego nad istotnymi obszarami życia politycznego, gospodarczego i społecznego, a być może nawet oddzielenie się tych okręgów od państwa rumuńskiego. Był to element walki politycznej rządzącej Partii Socjaldemokratycznej, która próbowała deprecjonować w miarę silną pozycję UDMR (Solak, 2004, s. 52).

Także obecnie „karta antywęgierska” bywa wykorzystywana do walki politycznej i powoduje zaognienie kontaktów na linii Bukareszt-Budapeszt. Po ostatnich wyborach w grudniu 2012 r. gdy nowo wybrany prefekt okręgu Covasna zdją ze swojego biura flagę seklerską zareagował ambasador węgierski w Rumunii, popierając żądania Seklerów dotyczące autonomii ${ }^{5}$. W odpowiedzi szef rumuńskiego ministerstwa spraw zagranicznych uznał, że słowa ambasadora są ingerencją w wewnętrzne sprawy państwa rumuńskiego. Do sytuacji odniósł się także wiceminister dyplomacji Weggier, apelując do władz miast węgierskich, aby protestacyjnie wywieszano na budynkach publicznych flagę Seklerów. Apel spotkał się z pozytywną reakcją w wielu miastach na Węgrzech (www.tvp.info..., 10.05.2013) $)^{6}$.

\footnotetext{
${ }^{5}$ Żądania te w pewnym sensie byly nawiązaniem do tzw. Węgierskiego Okręgu Autonomicznego istniejącego w latach 1952-1968 na obszarach, gdzie zamieszkiwali Seklerzy.

${ }^{6}$ Złoto-niebieską flagę Seklerów powieszono także na budynku parlamentu w Budapeszcie. Z obserwacji autora, poczynionych wiosną $2013 \mathrm{r}$., wynika, że flagi wiszą nie tylko przed budynkami publicznymi, ale także w miejscach niemających nic wspólnego $\mathrm{z}$,wielką polityką", $n p$. w budapeszteńskich halach targowych.
} 
Tzw. spór o flagę na nowo zatem zaognił sprawę węgierskiej mniejszości, co z pewnością nie sprzyja stosunkom obu państw. Kontakty te pozostają napięte ponieważ od czasu do czasu, gdy konflikt wydawałoby się wygasa, mają miejsce wydarzenia powodujące powrót do wrogiej retoryki. Nie zmienia to faktu, iż mniejszość węgierska w Rumunii pozostaje istotnym czynnikiem systemu politycznego tego państwa.

\section{Mniejszość niemiecka i jej przedstawiciele polityczni}

Polityczną reprezentacją mniejszości niemieckiej w Rumunii jest Demokratyczne Forum Niemców w Rumunii (rum. Forumul Democrat al Germanilor din România - FDGR, niem. Demokratisches Forum der Deutschen in Rumänien - DFDR). Forum założono w ostatnich dniach grudnia 1989 r., doszło do tego w Sibiu (Klein, 2010, s. 9-10). Miejscowość ta stała się z czasem nieformalną stolicą Forum. Ugrupowanie utworzyło swe koła terenowe i przystapiło do pierwszych wyborów, zarówno parlamentarnych, jak i lokalnych, w 1990 roku. Obecnie na czele ugrupowania stoi Paul Jürgen Porr, honorowym przewodniczącym jest Paul Philippi (www.fdgr.ro/de/conducerea/, 10.05.2013).

Godny podkreślenia jest fakt szybkiego zorganizowania się niemieckiej grupy mniejszościowej, tym bardziej, że nie była ona jednolita, gdyż Niemcy zamieszkiwali w różnych miejscach omawianego państwa - co stanowiło pochodną ich historycznego przybycia na różne obszary, które dopiero $\mathrm{z}$ czasem znalazły się w granicach państwa rumuńskiego. Problemem, który dotykał Niemców w Rumunii była przybierająca na sile fala wyjazdów członków tej grupy do RFN. Wśród wyjeżdżających z Rumunii w $1990 \mathrm{r}$. jedynie $20 \%$ emigrantów było pochodzenia rumuńskiego. Obok Niemców wyjeżdżali także, choć w mniejszym stopniu, Węgrzy (Andruş, 2009, s. 178).

Forum w początkowym okresie działalności oceniało, iż prawa mniejszości w Rumunii nie są realizowane. W przeciwieństwie do Węgrów nie zdecydowano się jednak na publiczne zajęcia stanowiska dotyczącego niespełniania zaleceń Rady Europy przez Rumunię. Zwyciężył realizm i chęć aktywnego udziału we wspólnych gremiach mających zajmować się sprawami mniejszości. Nie bez znaczenia dla tej grupy było także podpisanie w 1992 r. Traktatu o Przyjaźni między Niemcami a Rumunią (Mihok, 1999, s. $117-120)^{7}$.

FDGR reprezentuje różne poglądy polityczne, nie posiada jednej doktryny. Nie jest też formalnie partia, lecz organizacją pożytku publicznego. Ugrupowanie kładzie nacisk na zachowanie i ochronę identyfikacji kulturowej mniejszości, zwracając uwagę na 4 obszary działań: polityke, kulturę, sprawy społeczne oraz gospodarkę. W kwestiach politycznych akcentuje konieczność reprezentowania mniejszości narodowych w gremiach politycznych na szczeblu ogólnokrajowym i lokalnym oraz prawo do współdecydowania w sprawach, które związane są z grupami mniejszościowymi. FDGR opowiada się za zachowaniem i wsparciem istniejących instytucji kultury oraz systemu edukacji, w którym

\footnotetext{
${ }^{7}$ Normalizacja stosunków między RFN a Rumunią nastapiła zatem kilka lat wcześniej niż między Rumunią a Węgrami.
} 
istnieje możliwość pobierania nauki w języku ojczystym. Z kolei w sprawach społecznych zwraca uwagę na dalsze istnienie form organizacyjnych mniejszości, a w kwestiach gospodarczych na rozwój gospodarki rynkowej oraz wsparcie dla działalności małych i średnich przedsiębiorstw (Programm des, 9.05.2013).

Sukcesy wyborcze ugrupowania rodziły się z czasem, przełomem był rok 2000, kiedy to po raz pierwszy ugrupowanie stało się zauważalne na lokalnej scenie politycznej. W mieście Sibiu, położonym w centrum Siedmiogrodu, od 2000 r. burmistrzem jest przedstawiciel mniejszości niemieckiej Klaus Johannis. Zaskakującym dla niego samego był fakt wybrania go burmistrzem w prawie 170-tysięcznym mieście, w którym mieszkało jedynie 2,5 tys. Niemców (Johannis, 2010, s. 18). Poparcie dla Forum w Sibiu rosło stopniowo. Ugrupowanie posiadało w 23-osobowej radzie miasta najpierw 2-3 przedstawicieli, w 2000 r. już 6, w kadencji 2004-2008 aż 16 (sic!), od 2008 r. 14 (Klemens, 2010, s. 18). Tak wysokie wsparcie, wyrażane przez ludność w większości rumuńską, było uznaniem dla rządów Johannisa, który wyrósł na polityka o znaczeniu ponadregionalnym (www.derstandard..., 26.05.2013). Po ostatnich wyborach lokalnych Johannis ponownie został burmistrzem Sibiu, uzyskując poparcie prawie 78\% głosujących (www.adz.ro..., 26.05.2013). Cieszy się on wsparciem nie tylko ze strony swojej grupy etnicznej.

Szczebel lokalny, z powodu niewysokiej liczebności grupy, stanowi ważny punkt odniesienia w działaniach FDGR. Unaoczniają to wyniki ostatnich wyborów lokalnych z 2012 r. Przedstawiciele Forum znaleźli się w dwóch radach miejskich (Sibiu i Braszów) oraz 23 radach gmin w Banacie, Siedmiogrodzie i północnym Siedmiogrodzie. Urząd burmistrza lub wójta z ramienia Forum sprawuje 9 osób (http://www.fdgr.ro/de/alegeri..., 13.05.2013). W Siedmiogrodzie w miejscowości Avrig (niem. Freck) burmistrzem został Arnold Klingeis. Kolejne stanowiska burmistrza FDGR obsadziła w okręgu Satu Mare (przy granicy z Węgrami i Ukrainą), w miejscowościach: Ciumești (Schamagosch), Cămin (Kalmandi), Petreşti (Petrifeld), Tiream (Terem), Sanislău (Stanislau), Turulung (Turtebesch) i Urziceni (Schinal). Wziąwszy pod uwagę, iż w żadnej z wymienionych miejscowości Niemcy nie stanowią większości, wynik wyborczy należy uznać za sukces.

Na mniejsze poparcie FDGR mogła liczyć w wyborach parlamentarnych, co jest zrozumiałe z powodu liczebności grupy. W latach 90 . poparcie wyborcze dla ugrupowania oscylowało między prawie 24, a ponad 40 tysiącami głosów w skali kraju (Tontsch, 2001, s. 51-52). Wystarczało to do zdobycia jednego miejsca w Izbie Deputowanych. W ostatnich wyborach na FDGR oddano ponad 39 tys. głosów (prawie 16 tys. głosów więcej niż 4 lata wcześniej) (Die bei den Parlamentswahlen, 27.05.2013). Wskazuje to na otrzymywanie poparcia także spoza kręgów grupy etnicznej, co jest zresztą cechą charakterystyczną tego ugrupowania zarówno w wyborach ogólnokrajowych, jak i lokalnych. Forum uzyskało największe poparcie w okręgach Sibiu (ponad 10,7 tys. głosów), Cluj-Napoca (prawie 3,7 tys.), Timişoara (ponad 2,1 tys.) oraz w Bukareszcie (ponad 2,2 tys.).

W obecnej rumuńskiej Izbie Deputowanych przedstawicielem grupy niemieckiej jest poseł Ovidiu Gant wywodzacy się z Banatu. Pełni funkcję wiceprzewodniczącego Grupy Parlamentarnej Mniejszości Narodowych (http://www.cdep.ro/pls..., 13.05.2013) ${ }^{8}$. Warto dodać, iż w latach 2007-2009 Gant zasiadał w Parlamencie Europejskim, co również

${ }^{8}$ W latach 2007-2009 Gant zasiadal także w Parlamencie Europejskim. 
było widocznym sukcesem politycznym grupy. Wykaz przedstawicieli mniejszości niemieckiej w Izbie Deputowanych po 1990 r. zawarty jest w tabeli 3.

\section{Tabela 3}

Przedstawiciele mniejszości niemieckiej w Izbie Deputowanych po 1990 roku

\begin{tabular}{|c|l|}
\hline \hline Kadencja & \multicolumn{1}{|c|}{ Przedstawiciele } \\
\hline $1992-1996$ & Eberhard WITTSTOCK \\
\hline $1996-2000$ & Werner BRÜCK, Eberhard WITTSTOCK \\
\hline $2000-2004$ & Eberhard WITTSTOCK \\
\hline $2004-2008$ & Ovidiu GANT \\
\hline $2008-2012$ & Ovidiu GANT \\
\hline od 2012 & Ovidiu GANT \\
\hline
\end{tabular}

Źródlo: Opracowanie własne na podstawie http://www.cdep.ro/ pls..., 27.05.2013. W kadencji 1996-2000 Eberhard Wittstock sprawował mandat po rezygnacji Wernera Brücka w 2007 r.

\section{Podsumowanie}

Transformacja polityczna i gospodarcza, dokonująca się w Rumunii po upadku systemu komunistycznego, przyczyniła się do poprawy położenia prawnego mniejszości narodowych w tym kraju. W konsekwencji grupy mniejszościowe stały się faktycznym i trwałym uczestnikiem systemu politycznego i partyjnego analizowanego państwa.

Obecność mniejszości na scenie politycznej Rumunii nie zaskakuje, gdyż stanowią one w sumie ponad 10\% mieszkańców kraju. Jednak większość grup mniejszościowych to grupy nieliczne, często rozproszone. Na tym tle, jako stosunkowo liczni, ale i najlepiej zorganizowani, jawią się Węgrzy i Niemcy, którzy zamieszkują dodatkowo zwarte obszary. Obie grupy są regularnie reprezentowane w obu izbach parlamentu rumuńskiego, po $1990 \mathrm{r}$.

Liczniejszą reprezentację - najczęściej ponad 20-osobową w Izbie Deputowanych - posiadają Węgrzy. Nie korzystają oni z wyborczego uprzywilejowania (pozwalającego na obecność mniejszości w parlamencie bez konieczności pokonania ustawowej bariery $5 \%$ głosów), ponieważ, jak dotąd, bez większych problemów uzyskiwali poparcie na poziomie wyższym. W ostatnich wyborach próg ten przekroczyli nieznacznie (z powodu rozłamu w ich najważniejszej organizacji). W przypadku tej grupy zachowanie jedności organizacyjnej, wyrażającej się np. startem w wyborach jednego ugrupowania, jest o tyle istotne, że pozwala na stosunkowo liczną obecność w parlamencie. W przeciwnym razie reprezentacja ta będzie symboliczna.

Mniejszość niemiecka, znacznie mniej liczna, jest aktywna przede wszystkim na szczeblu lokalnym posiadając w kilku miejscowościach swoich burmistrzów i reprezentantów w radach miast i gmin. W przeciwieństwie do węgierskiej UDMR ugrupowanie mniejszości niemieckiej cieszy się poparciem także innych grup etnicznych, o czym świadczą wyniki wyborów lokalnych, jak i ogólnopaństwowych. Tym samym FDGR po- 
siada możliwość rozszerzenia swojego elektoratu w przyszłości, czego nie można powiedzieć o UDMR.

W perspektywie najbliższych lat nie należy oczekiwać znaczących zmian związanych z obecnością ugrupowań mniejszości węgierskiej i niemieckiej na rumuńskiej scenie politycznej. W przypadku pierwszej grupy istotne znaczenie będzie miał rozwój stosunków Rumunii z Wegrami. Od czasu do czasu mają w nich miejsce wypowiedzi ,podgrzewające atmosferę", a nie przyczyniające się do konstruktywnego rozwiązywania istniejących problemów. W konsekwencji tego poparcie dla UDMR jest ograniczone wyłącznie do węgierskiej grupy etnicznej i nie będzie rosło. Tego rodzaju problemy nie dotyczą FDGR, lecz ugrupowanie to może mieć istotne znaczenie co najwyżej na szczeblu lokalnym.

\section{Bibliografia}

Alegeri pentra Camera Deputatilor si Senat 9 decembrie 2012 (2012), http://www.becparlamentare2012.ro/rezultate.html, 8.05.2013.

Alegeri locale I iunie 2008. Situatia mandatelor repartizate pe partide (2008), http://www.beclocale2008.ro/documm/Mandate\%20pe\%20Partide/manpart.pdf, 23.05.2013.

Alegeri locale 10 iunie +24 iunie 2012. Situatia mandatelor repartizate pe partide (2012), http://www.beclocale2012.ro/DOCUMENTE\%20BEC/REZULTATE\%20FINALE/10\%20Iunie\%2024\%20Iunie/ PDF/Statistici/Situatie_mandate_part.pdf, 23.05.2013.

Andruş C. (2009), Ewolucja zjawiska migracji we wspólczesnej Rumunil, w: Dwie dekady zmian: Rumunia 1989-2009, red. K. P. Marczuk, Warszawa.

Anuarul statistic 2012 (2013). Wyd. Institutul national de Statistica, București, http://www.insse.ro/ cms/files/Anuar\%20statistic/08/8.\%20Educatie_\%20en.pdf, 25.06.2013.

Aron O. (2009), Zmiany na scenie politycznej postkomunistycznej Rumunii, w: Dwie dekady zmian: Rumunia 1989-2009, red. K. P. Marczuk, Warszawa.

Batko-Jakubiak S. (2010), System partyjny Rumunii, w: B. Kosowska-Gąsto1, Systemy partyjne państw Unii Europejskiej, Kraków.

Böhm J. (2003), Die Gleichschaltung der Deutschen Volksgruppe in Rumänien und das Dritte Reich 1941-1944, Frankfurt/M.

Brodziński W. (2006), System konstytucyjny Rumunii, Warszawa.

Burakowski A., Stan M. (2012), Kraj smutny peten humoru. Dzieje Rumunii po 1989 roku, Warszawa.

Deutsches Leben in Mittel-Osteuropa. Die Gerufenen (2009), Berlin.

Die bei den Parlamentswahlen 2008 und 2012 vom DFDR erzielte Stimmenanzahl, http://www.fdgr.ro/ de/alegeri_locale/, 2.05.2013.

Gabanyi A. U. (1998), Systemwechsel in Rumänien. Von der Revolution zur Transformation, München.

Gesetz Nr 215 vom 23. April 2001 über die örtliche óffentliche Verwaltung (Auszug), w: G. H. Tontsch, Minderheitenschutz im östlichen Europa. Rumänien.

Hartl H. (1987), Die Deutschen in Rumänien nach 1945, w: Die Deutschen in Rumänien heute. Ihr Schicksal als schwindende nationale Minderheit, Starnberg.

$\mathrm{http}: / /$ derstandard.at/1254311368020/Klaus-Johannis-soll-Uebergangspremier-werden, 26.05.2013.

http://tvp.info/informacje/swiat/spor-wegier-z-rumunia-o-flage-szeklerow/10100910, 10.05.2013.

http://www.adz.ro/artikel/artikel/fuer-gedeihendes-hermannstadt/, 26.05.2013. 
http://www.cdep.ro/pls/parlam/structura.gp?idg=5, 29.05.2013.

http://www.cdep.ro/pls/parlam/structura.gp?idl=2, 28.05.2013.

http://www.cdep.ro/pls/parlam/structura.mp?idm $=138 \& \mathrm{cam}=2 \& \mathrm{leg}=2012 \& \mathrm{pag}=1 \& \mathrm{idl}=1$, 13.05.2013.

http://www.europarl.europa.eu/meps/pl/search.html?country=RO, 28.05.2013.

http://www.fdgr.ro/de/alegeri_locale/lokalwahlen.html, 13.05.2013.

http://www.fdgr.ro/de/conducerea/index.html, 10.05.2013.

http://www.ipu.org/parline-e/reports/2261_E.htm, 28.05.2013

http://www.senat.ro/ComponentaGrupuri.aspx?Zi\&GrupID=45df3d5e-0653-42f5-96cb-1759638b1065, 29.05 .2013$.

Illyés E. (1981), Nationale Minderhaiten in Rumänien. Siebenbürgen im Wandel, Wien.

Janusz G. (2006), Statystyczny obraz mniejszości narodowych we wspólczesnej Europie, w E. Michalik, H. Chałupczak, Mniejszości narodowe i etniczne w procesach transformacji oraz integracji, Lublin.

Johannis K. (2010), Im Amt des Bürgermeisters, w: Zwanzig Jahre Demokratisches Forum der Deutschen in Hermannstadt, red. H. Klein, Hermannstadt.

Klein H. (2010), Zwanzig Deutsches Forum Hermannstadt, w: Zwanzig Jahre Demokratisches Forum der Deutschen in Hermannstadt, red. H. Klein, Hermannstadt.

Klemens K. (2010), Politische Vertretung und Beziehungen zu anderen politischen Vereinen und Parteien, w: Zwanzig Jahre Demokratisches Forum der Deutschen in Hermannstadt, red H. Klein, Hermannstadt.

Kopyś T. (2001), Kwestia narodowościowa na ziemiach Korony Świętego Stefana w latach 1867-1918, Kraków.

Kroner M. (1987), Die Nationalittenpolitik Rumäniens 1918-1945. Mit besonderer Berücksichtigung der Siebenbürger Sachsen, w: Die Deutschen in Rumänien heute. Ihr Schicksal als schwindende nationale Minderheit, Starnberg.

Maksimiec A. (2012), Mniejszości narodowe i etniczne w krajach Europy Środkowej $i$ Wschodniej po przystapieniu do Unii Europejskiej, Warszawa.

Marczuk K. P. (red.) (2009), Dwie dekady zmian: Rumunia 1989-2009, Warszawa.

Mihok B. (1999), Vergleichende Studie zur Situation der Minderheiten in Ungarn und Rumänien (1989-1996) unter besonderer Berücksichtiging der Roma, Frankfurt/M.

Nägler T. (1999), Die Rumänen und die Siebenbürger Sachsen vom 12. Jahrhundert bis 1848 , Hermannstadt-Sibiu.

Programm des DFDR, www. fdgr.ro, 9.05.2013.

Romania in figures 2012. Statistical abstract, Bucharest.

Roth H. (1981), Zum Wandel der politischen Strukturen bei den Siebenbürger Sachsen 1918 bis 1933. w: Minderheit und Nationalstaat. Siebenbürgen seit dem ersten Weltkrieg, red. H. Roth, Köln-Weimar-Wien.

Solak J. (2004), Rumunia. Narodowe i ponadnarodowe aspekty integracji ze strukturami euroatlantyckimi, Torun.

Sterbling A. (1997), Kontinuität und Wandel in Rumänien und Südeuropa. Historisch-soziologische Analysen, München.

Szász Z. (1995), Vom Staatsvolk zur Minderheit - die Ungarn in Siebenbürgen während der Zwischenkriegszeit, w: Minderheit und Nationalstaat. Siebenbürgen seit dem ersten Weltkrieg, red. H. Roth, Köln-Weimar-Wien.

Szász Z. (2003), Recent Development In Romanian Political Llfe, w: A New Balance: Democracy and minorities In Post-Communist Europe, red. M. Robotin, L. Salat, Budapest. 
Tontsch G. H. (1995), Der Minderheitenschutz in Rumänien, w: G. Brunner, G. H. Tontsch, Der Minderheitenschutz in Ungarn und in Rumänien, Bonn.

Tontsch G. H. (2001), Minderheitenschutz im östlichen Europa. Rumänien, http://www.uni-koeln.de/ jur-fak/ strecht/minderheitenschutz/Vortraege/Rumaenien/Rumaenien_Tontsch.pdf, 12.05.2013.

Willaume M. (2004), Rumunia, Warszawa.

Willaume M. (2007), Rumunia, w: A. Koseski, M. Willaume, Nowe kraje Unii Europejskiej. Butgaria, Rumunia, Warszawa.

\title{
Political groupings of national minorities in Romania. The example of Hungarians and Germans
}

\begin{abstract}
Summary
Among other things, the transformation in Romania has allowed for the participation of the representatives of national minorities in the political system of state. This is illustrated by the case of Hungarians, who according to the 2011 census account for over $1,237,000$ of the population, and that of approximately 37,000 Germans.

Both groups take a regular and active part in both national and local elections. Hungarians are represented by the UDMR, a group that wins support in excess of $5 \%$ of the votes, thus regularly getting over 20 seats in the Chamber of Deputies and approximately ten seats in the Senate. The Germans are represented by the FDGR, with considerably weaker support, which translates into only a single seat in the parliament. Both minorities play a significant role in regional elections, even though the German population is considerably smaller than that of the Hungarians. The town of Sibiu is one example of their electoral success.

The significance of both groups should not be expected to change significantly in the future. Unlike in the case of the Hungarians, support for the Germans is higher than might be expected from their number. This follows from the fact that the issue of the German minority in Romania has never stirred such tensions as that of the Hungarians, both in domestic and international relations. Therefore, casting a vote for the FDGR does not have to follow from being a member of the German minority, allowing the party to win potential voters.
\end{abstract}

Key words: Romania, Transylvania, national minority, Hungarians, Germans 